\title{
Reliable Determinations of Protein-Ligand Interactions by Direct ESI-MS Measurements. Are We There Yet?
}

\author{
Elena N. Kitova, ${ }^{1}$ Amr El-Hawiet, ${ }^{1}$ Paul D. Schnier, ${ }^{2}$ John S. Klassen ${ }^{1}$ \\ ${ }^{1}$ Alberta Glycomics Centre and Department of Chemistry, University of Alberta, Edmonton, Alberta, Canada T6G 2G2 \\ ${ }^{2}$ Molecular Structure, Amgen, Thousand Oaks, CA, USA
}

\begin{abstract}
The association-dissociation of noncovalent interactions between protein and ligands, such as other proteins, carbohydrates, lipids, DNA, or small molecules, are critical events in many biological processes. The discovery and characterization of these interactions is essential to a complete understanding of biochemical reactions and pathways and to the design of novel therapeutic agents that may be used to treat a variety of diseases and infections. Over the last $20 \mathrm{y}$, electrospray ionization mass spectrometry (ESI-MS) has emerged as a versatile tool for the identification and quantification of protein-ligand interactions in vitro. Here, we describe the implementation of the direct ESI-MS assay for the determination of protein-ligand binding stoichiometry and affinity. Additionally, we outline common sources of error encountered with these measurements and various strategies to overcome them. Finally, we comment on some of the outstanding challenges associated with the implementation of the assay and highlight new areas where direct ESI-MS measurements are expected to make significant contributions in the future.
\end{abstract}

Key words: Protein-ligand interaction, Electrospray ionization mass spectrometry, Association constant, Binding assay, Library screening

\section{Introduction}

$\mathrm{T}$ The noncovalent association and dissociation between 1 protein and ligands (e.g., other proteins, carbohydrates, lipids, DNA or small molecules) are critical to numerous physiological and pathological processes, such as cell growth and differentiation, fertilization, in recognition processes, such as cell-cell adhesion and immune responses against pathogens, and in diverse disease mechanisms, including inflammation and bacterial and viral adherence. The discovery and characterization of protein-ligand complexes (i.e., elucidating their structures and dynamics and quantifying the kinetic and thermodynamic parameters that describe the interactions) are essential to a complete description of biochemical reactions and pathways. Understanding the molecular basis of protein recognition, the

Correspondence to: John Klassen; e-mail: john.klassen@ualberta.ca relationship between structure and binding selectivity and affinity, in addition to being of fundamental importance, facilitates the design of novel therapeutics that may be used to treat a variety of human diseases. For example, most drug discovery campaigns are currently run using a "target centric" paradigm in which compounds that bind specifically and selectively with high affinity to a protein target or family of targets are developed to inhibit the protein's activity or modulate its function.

A wide variety of analytical methods are available to identify and quantify protein-ligand interactions in vitro, with each method having particular strengths and weaknesses. The most common techniques for quantifying protein-ligand binding in vitro include surface plasmon resonance (SPR) spectroscopy [1], isothermal titration calorimetry (ITC) [2], frontal affinity chromatography combined with mass spectrometry detection [3], enzymelinked immunosorbent assay [4], ThermoFluor assay [5] and nuclear magnetic resonance spectroscopy [6]. 
Another method for the analysis of protein-ligand interactions in solution, which is the focus of the present article, is based on direct electrospray ionization mass spectrometry (ESI-MS) measurements [7-10]. The direct ESI-MS assay, also commonly referred to as the ESI-MS titration method, exploits the gentle nature of the ESI process, which allows noncovalent interactions to be transferred intact from solution to the gas phase. Analytical advantages of the direct ESI-MS assay include simplicity (no labeling or immobilization), speed (mass spectra can typically be acquired in less than a minute), low sample consumption $(<\mathrm{fmol}$ of sample consumed per analysis when using nanoflow ESI), specificity (ability to directly measure binding stoichiometry, analyze mixtures and measure multiple equilibria simultaneously), selectivity (complexes can be further interrogated using additional stages of MS combined with ion activation methods, ion mobility spectrometry, or other MS-based methods).

The earliest examples of the application of ESI-MS for the direct detection of noncovalent protein complexes from aqueous solutions appeared 20 y ago. In 1991, Katta and Chait reported on the ESI-MS detection of the intact globinheme interaction of myoglobin [11]. That same year, analysis of a receptor-ligand complex was reported by Ganem et al. [12]. Soon after the initial reports demonstrating that specific protein-ligand interactions could be detected by ESI-MS appeared, the technique was exploited for the determination of the protein-ligand association constants $\left(\mathrm{K}_{\mathrm{a}}\right)$. The first example of the application of the direct ESI-MS assay to quantify protein-ligand affinities was reported in 1993 by Loo and co-workers [13]. By performing ESI-MS measurements on the ribonuclease Sprotein/S-peptide complex over a range of temperatures, they were able to establish not only $\mathrm{K}_{\mathrm{a}}$ values but also estimate the enthalpy $\left(\Delta \mathrm{H}_{\mathrm{a}}\right)$ and entropy $\left(\Delta \mathrm{S}_{\mathrm{a}}\right)$ of association [13].

Despite the early promise of the direct ESI-MS assay as a tool for quantifying protein-ligand interactions in vitro, the widespread adoption of the technique has been limited by concerns of reliability and reproducibility. The technique works well for some complexes and gives results that agree quantitatively with data obtained with more established assays, but it does not work for other complexes. Furthermore, different instruments sometimes produce divergent results for the same interaction. However, over the past decade, a number of methodological advances have significantly improved the reliability and applicability of the ESI-MS assay, and affinities measured for a multitude protein-ligand complexes, as well as other types of biological complexes have been shown to be in agreement with values determined by other analytical methods [14-23]. So, does this mean that the ESI-MS assay has matured to the point where the technique can be reliably used by researchers who do not have extensive training in MS? In an effort to answer this question, a description of the major sources of errors and technical challenges associated with the direct ESIMS measurements of protein-ligand interactions is given below, along with an examination of current strategies for minimizing the errors and potential shortcomings.

\section{Direct ESI-MS Assay. How does it Work?}

As a starting point, it is worthwhile to briefly review the implementation of the direct ESI-MS assay for measuring the affinity of protein-ligand interactions. The assay is based on the detection and quantification of free and ligand-bound protein ions by ESI-MS (Figure 1). The $\mathrm{K}_{a}$ for a given protein-ligand interaction is determined from the ratio $(R)$ of total abundance $(A b)$ of ligand-bound and free protein ions, as measured by ESI-MS for solutions of known initial concentrations of protein $\left([\mathrm{P}]_{\mathrm{o}}\right)$ and ligand $\left([\mathrm{L}]_{\mathrm{o}}\right)$. For a $1: 1$ protein-ligand complex Equation (1), $\mathrm{K}_{\mathrm{a}}$ is calculated using Equation (2):

$$
\begin{gathered}
\mathrm{P}+\mathrm{L} \rightleftharpoons \mathrm{PL} \\
\mathrm{K}_{\mathrm{a}}=\frac{R}{[\mathrm{~L}]_{\mathrm{o}}-\frac{R}{1+R}[\mathrm{P}]_{o}}
\end{gathered}
$$

where $R$ is given by Equation (3):

$$
\frac{[\mathrm{PL}]_{e q}}{[\mathrm{P}]_{e q}}=\frac{A b(\mathrm{PL})}{A b(\mathrm{P})}=R
$$

It is important to emphasize that the abundance of all detected PL and P ions should be included in the calculation of $R$. After all, there is only one concentration ratio in solution. The sometimes-used practice of evaluating $\mathrm{K}_{\mathrm{a}}$ based on the abundance of PL and P ions of a particular charge state or reporting charge state dependent $K_{a}$ values should be avoided. Care should also be taken extracting relative abundances from deconvoluted "zero charge" mass spectra obtained from probabilistic methods such as the popular maximum entropy method. While commercial deconvolution algorithms are useful for reliably obtaining the correct "zero charge" mass, it is notoriously difficult to extract accurate peak heights or areas with these methodologies [24].

Normally, $\mathrm{K}_{\mathrm{a}}$ for a particular protein-ligand interaction is not determined at a single concentration of $\mathrm{P}$ and the $\mathrm{L}$ but rather from measurements performed at a number of different concentrations or from a titration experiment, wherein the concentration of one analyte (normally $\mathrm{P}$ ) is fixed and the concentration of the other is varied [21]. The 
(a)

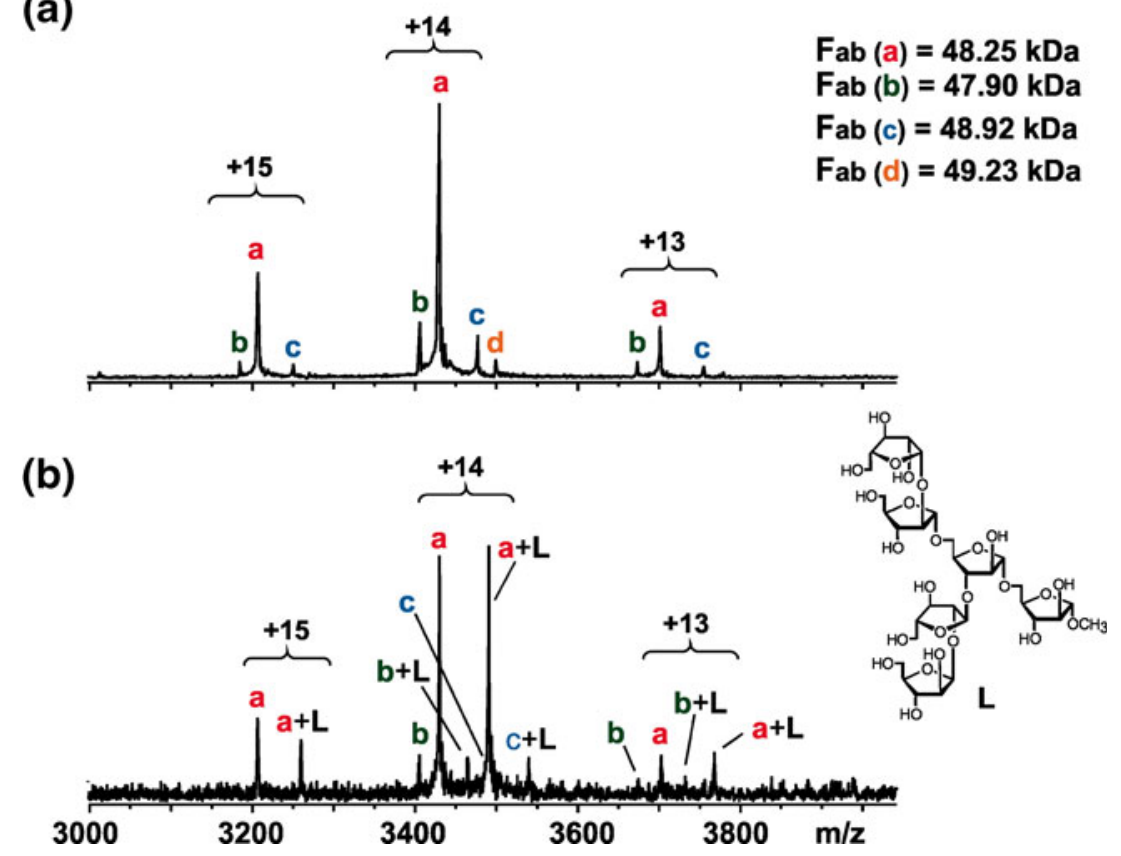

Figure 1. ESI mass spectra measured for a solution of (a) $12 \mu \mathrm{M}$ antigen binding fragment (Fab) of the monoclonal anitbody CS-35 and (b) $12 \mu \mathrm{M} \mathrm{Fab}$ and $12 \mu \mathrm{M}$ of a hexasaccharide ligand (L). Papain digestion of CS-35 produces four different Fab proteins (labeled $\mathrm{a}-\mathrm{d}$ ). The $\mathrm{K}_{\mathrm{a}}$ value determined by ESI-MS $\left(1.6 \pm 0.2 \times 10^{5} \mathrm{M}^{-1}\right)$ agrees with values reported by isothermal titration calorimetry $\left(1.7 \pm 0.2 \times 10^{5} \mathrm{M}^{-1}\right)$ and frontal affinity chromatography $\mathrm{MS}\left(1 \times 10^{5} \mathrm{M}^{-1}\right)[17]$

value of $\mathrm{K}_{\mathrm{a}}$ can be extracted using nonlinear regression analysis of the experimentally determined concentrationdependence of the fraction of ligand-bound protein, i.e., $R /(R+1)$, which is given by the following expression:

$R /(R+1)=\frac{1+\mathrm{K}_{\mathrm{a}}[\mathrm{P}]_{\mathrm{o}}+\mathrm{K}_{\mathrm{a}}[\mathrm{L}]_{\mathrm{o}}-\sqrt{\left(1+\mathrm{K}_{\mathrm{a}}[\mathrm{P}]_{o}-\mathrm{K}_{\mathrm{a}}[\mathrm{L}]_{o}\right)^{2}+4 \mathrm{~K}_{\mathrm{a}}[\mathrm{L}]_{o}}}{2 \mathrm{~K}_{\mathrm{a}}[\mathrm{P}]_{o}}$

In practice, ESI-MS binding measurements are usually limited to $R$ values ranging from approximately 0.05 to 20 and $\mathrm{P}$ and $\mathrm{L}$ concentrations in the 0.1 to $1000 \mu \mathrm{M}$ range. It follows that $\mathrm{K}_{\mathrm{a}}$ values accessible with the direct ESI-MS binding assay range from approximately $10^{3}$ to $10^{7} \mathrm{M}^{-1}$. However, interactions with much larger $\mathrm{K}_{\mathrm{a}}$ values can be probed using competitive binding and direct ESI-MS measurements, vide infra.

Two important features of the ESI-MS assay are the abilities to directly establish the stoichiometry of protein complexes and to measure multiple binding equilibria simultaneously. These features enable the determination of both the macroscopic and microscopic $\mathrm{K}_{\mathrm{a}}$ values for sequential binding of $\mathrm{L}$ to $\mathrm{P}$. As a result, ESI-MS is ideally suited for characterizing allosteric binding. The ESI-MS assay also naturally lends itself to monitoring and quantifying protein-ligand interactions in solutions containing mixtures of ligands and/or proteins [25-33]. Not surprising- ly, an emerging ESI-MS application is screening libraries of compounds against target proteins to identify specific interactions. The ESI-MS assay is also well-suited for competitive binding experiments in which multiple proteins or ligands compete for binding partners. The combination of competitive binding experiments and ESI-MS detection has been exploited in numerous studies to extract binding data that could not be measured directly by ESI-MS. For example, the range of $\mathrm{K}_{\mathrm{a}}$ values that can be measured by ESI-MS can be dramatically extended through competition experiments involving multiple proteins that exhibit a range of affinities for the same L $[34,35]$. More recently, it was demonstrated that the affinities of labile PL complexes that are prone to dissociation in the gas phase are readily determined by monitoring the interaction between the $\mathrm{P}$ of interest and a "reference" L, which binds competitively and forms a stable (in the gas phase) complex with $\mathrm{P}$, in the presence of L $[23,36]$.

\section{Potential Pitfalls}

While it is relatively easy to acquire mass spectra of proteinligand complexes using modern ESI-MS instrumentation, determining whether the binding data are meaningful is not always straightforward. The successful implementation of the direct ESI-MS assay requires that the equilibrium abundance ratio of bound-to-free protein present in bulk solution is preserved both during the ESI process and in the 
gas phase. Physical or chemical processes that alter this ratio will lead to incorrect $\mathrm{K}_{a}$ values and, potentially, obscure the true binding stoichiometry. There are four common sources of error associated with the ESI-MS measurements: (1) nonuniform response factors, (2) in-source dissociation, (3) nonspecific ligand-protein binding, and (4) ESI-induced changes in solution $\mathrm{pH}$ and temperature. Each of these sources of error is briefly described below, along with current strategies for minimizing their effects on the binding measurements.

\section{Non-uniform Response Factors}

As described above, the abundances of P and PL measured by ESI-MS are related to the solution concentration by a response factor $(R F)$, which collectively accounts for the ionization and detection efficiencies, Equation (5):

$$
\begin{aligned}
{[\mathrm{PL}] /[\mathrm{P}] } & =R F_{\mathrm{P}} A b(\mathrm{PL}) / R F_{\mathrm{PL}} A b(\mathrm{P}) \\
& =R F_{\mathrm{P} / \mathrm{PL}}(A b(\mathrm{PL}) / A b(\mathrm{P}))
\end{aligned}
$$

Underlying Equations (2) and (4) is the assumption of uniform $R F$ values (i.e., $R F_{\mathrm{P} / \mathrm{PL}} \approx 1$ ). This assumption is generally valid in cases where $\mathrm{L}$ is small compared to $\mathrm{P}$, such that the size and surface properties of the P and PL are similar [14-23, 34, 37, 38]. While there are no firm guidelines suggesting when this approximation is valid, it typically holds in cases where the molecular weight of PL and $\mathrm{P}\left(\mathrm{MW}_{\mathrm{PL}}\right.$ and $\mathrm{MW}_{\mathrm{P}}$, respectively) are similar (i.e., $\mathrm{MW}_{\mathrm{PL}} / \mathrm{MW}_{\mathrm{P}} \leq 110 \%$ [37]). However, there are cases where the ESI-MS response of a protein complex is significantly different than the response of the free protein [39, 40]. In fact, non-uniform ESI-MS response factors are generally expected in the case of protein-protein interactions. It is important to note that $R F \mathrm{~s}$ depend on many factors - the size and structure of $\mathrm{P}$ and PL, the ESI conditions and the instrumental parameters used for the measurements - and it is often possible to "tune" the experimental conditions to achieve the correct $R$ value (based on the known $\mathrm{K}_{\mathrm{a}}$ ). Such an approach may be appropriate when investigating structurally-related interactions. However, it is not generally recommended and should be used with caution.

A variety of strategies have been developed to minimize the effects of non-uniform $R F \mathrm{~s}$ on the determination of $\mathrm{K}_{\mathrm{a}}$ values. One approach involves the introduction of the $R F_{\mathrm{P} / \mathrm{PL}}$ term as an adjustable parameter in an appropriate binding model, which is fit to the experimental data [39-44]. This approach can also be used to account for in-source dissociation [40], and can be used when complexes of variable stoichiometry are present in solution [40, 43]. However, this method requires fitting a model with multiple adjustable parameters to the titration data and, therefore, high quality experimental data are required to obtain reliable $\mathrm{K}_{\mathrm{a}}$ values [42]. Furthermore, this approach is based on the assumption that $R F_{\mathrm{P} / \mathrm{PL}}$ is independent of concentration, at least over the range of the concentrations investigated. While there have been several successful demonstrations of this strategy, the generality of the approach has not been established. A variation on this method involves the use of an internal standard (IS). An appropriate IS is one that is similar (MW and surface activity) to the analyte of interest, but which does not bind to L [43]. The advantage of this approach is that changes/fluctuations in $R F_{\mathrm{P} / \mathrm{PL}}$ due to concentration, instability in the ESI, or other factors are reflected, at least to some extent, in the abundance of the IS. An alternative strategy involves monitoring the abundance of L, relative to that of an IS, as $[\mathrm{P}]_{\mathrm{o}}$ is varied [45]. In this assay, the IS resembles L but does not bind to P. The abundance ratio of L to IS ions serves to quantify the changes in $[\mathrm{L}]$ in solution as a function of $[\mathrm{P}]_{\mathrm{o}}$. This approach shows promise for quantifying ligand interactions with proteins and protein complexes that are difficult to detect directly by ESI-MS due to size or heterogeneity.

\section{In-Source Dissociation}

Collision-induced dissociation of gaseous ions of PL complexes during ESI-MS analysis can alter the relative abundance of PL and P ions. For a 1:1 PL complex, insource dissociation will necessarily decrease the magnitude of $\mathrm{K}_{\mathrm{a}}$. In the extreme case, where no PL ions survive to detection, in-source dissociation results in a false negative. The influence of in-source dissociation on binding measurements depends on the configuration of the ion source used, the choice of instrumental parameters and the size and gasphase stability of the complex. The stability of PL complexes in the gas phase is determined, in part, by the nature of the specific interactions in solution. Complexes stabilized in solution predominantly by weak or a small number of intermolecular interactions generally exhibit low gas phase stabilities and are susceptible to in-source dissociation [46-49]. However, it is important to note that the gas-phase stabilities of PL complexes generally do not parallel the solution binding affinities. For example, some PL complexes, which are stabilized by strong ionic interactions in solution, exhibit low gas phase stabilities [47], while some PL complexes formed by hydrophobic bonding are quite stable in the gas phase [23, 50, 51]. Collisional heating of gaseous ions may occur at various stages during the ion sampling process, such as within the heated metal sampling capillary (if used), in the nozzle (or orifice)skimmer region, and during accumulation of ions within external rf multipole storage devices (e.g., hexapole) [14, 36, $47,50,51]$. Usually, the occurrence of in-source dissociation can be identified from changes in $R$ resulting from changes in ion source parameters, in particular voltage differences in regions of high pressure (e.g., nozzle-skimmer voltages), that influence the internal energy of the ions. Identifying false negatives can be extremely challenging, particularly for complexes that rapidly dissociate at room temperature, and 
often requires the use of competitive binding experiments in order to confirm the absence of binding in solution. Recently, the use of pulsed hydrogen-deuterium exchange (HDX) for identifying the occurrence of in-source dissociation involving multiprotein complexes was demonstrated [52].

Low temperatures (drying gas, sampling capillary), low potentials across lens elements, and short accumulation times are essential for obtaining reliable $\mathrm{K}_{\mathrm{a}}$ values for PL complexes susceptible to in-source dissociation. However, there are usually trade-offs between the use of so-called "gentle" source conditions and signal intensity. Thus, a balance must be found between minimizing the extent of insource dissociation and achieving adequate protein ion signal. In cases where gentle sampling conditions do not eliminate the occurrence of in-source dissociation, the employment of stabilizing additives may prove beneficial. For example, the addition of imidazole to solution, at high concentration $(>1 \mathrm{mM})$, has been shown to prevent gas phase dissociation of the ions of a number of different PL interactions, including protein-carbohydrate, protein-fatty acid, and protein-small molecule complexes [23, 47, 50]. The origin of the stabilizing effects of imidazole is believed to be due, at least in part, to enhanced evaporative cooling resulting from the dissociation of nonspecific imidazole adducts from the gaseous PL ions [47]. Additionally, the use of imidazole, which has a relatively high gas phase basicity and a relatively low gas phase acidity [53, 54], may also lead to a reduction in the charge states of the protein complex ions. The lower charge state complex ions may exhibit higher kinetic stabilities and be more resistant to in-source dissociation. A practical issue related to the addition of imidazole to solution is that, at high concentration, it tends to suppress the P and PL ion signals. Recently, it was shown that the introduction of imidazole vapor to the ion source also protects complexes against in-source dissociation [50]. It has also been shown that the presence of a high partial pressure of $\mathrm{SF}_{6}$ in the ion source reduces the extent of insource dissociation for some complexes [50]. Lowering the temperature of the ion source of the mass spectrometer (i.e., cold spray) has been suggested as a means of preserving non-covalent interactions during ESI-MS analysis [55]. Although there have been reports describing the application of cold spray for detection of labile complexes [55-57], it is not clear in many instances whether the complexes detected correspond to species present in solution or formed by nonspecific binding during the ESI process.

In cases where it is not possible to eliminate in-source dissociation, a competitive binding assay, such as the reference ligand ESI-MS method, may be used [36]. In this approach, the direct ESI-MS assay is used to monitor binding of a reference ligand $\left(\mathrm{L}_{\mathrm{ref}}\right)$ to $\mathrm{P}$ in order to quantify the PL interaction. Two basic requirements are necessary for a suitable $L_{\text {ref, }}$, which are that it binds competitively to $P$ in solution with a known affinity and that the $\mathrm{PL}_{\text {ref }}$ complex is kinetically stable (on the timescale of the measurement) in the gas phase. This method has proven particularly useful for the analysis of PL interactions that are kinetically unstable in the gas phase at room temperature [23].

\section{Nonspecific Binding}

It is well established that, during the ESI process, free L can bind nonspecifically to $\mathrm{P}$ and $\mathrm{PL}$ (or $\mathrm{PL}_{q}$ in general) due to the concentration effects, resulting in false positives. Consequently, the observation of gaseous ions corresponding to a particular PL complex does not, by itself, establish the presence of that interaction in solution. The observation of multiple ligands bound to the target protein with a Poisson-like distribution is a tell-tale sign of occurrence of nonspecific ligand binding. Changes in the magnitude of $\mathrm{K}_{\mathrm{a}}$ with changes in ligand concentration may also alert to the occurrence of nonspecific ligand binding. The formation of nonspecific PL complexes can be understood in the context of the charge residue model of ESI (Figure 2) [58]. According to the charge residue model, the initial ESI droplets undergo solvent evaporation until they come close to Rayleigh limit, at which point they undergo fission, releasing several small multiply charged nanodroplets (often referred to as offspring or progeny droplets) containing no analyte or one or more molecules of analyte. Solvent evaporation from the nanodroplets ultimately yields gaseous ions. If a nanodroplet contains two or more analyte molecules, nonspecific intermolecular interactions can occur as the droplet evaporates to dryness, leading to the formation of nonspecific complexes.

The probability of the nanodroplets containing more than one analyte molecule increases with analyte concentration [59]. Therefore, a general strategy for minimizing the occurrence of nonspecific ligand binding involves limiting the concentration of L. However, high ligand concentrations $(>0.05 \mathrm{mM})$ are typically required to detect weak $\left(\mathrm{K}_{\mathrm{a}}<\right.$ $10^{4} \mathrm{M}^{-1}$ ) PL interactions. In such cases, nonspecific binding is often unavoidable. It was, at one time, believed that the gaseous ions of PL complexes formed from nonspecific interactions during the ESI process would be less stable than the corresponding ions formed from specific interactions in solution [60]. However, kinetic data measured for the dissociation of gaseous PL ions formed from specific and nonspecific protein-carbohydrate interactions revealed that the nonspecific interactions can be kinetically more stable than those originating from solution [61]. As a result, it is generally not possible to eliminate nonspecific interactions by heating the gaseous ions in the source (i.e., selective insource dissociation).

A number of strategies have been proposed to correct ESI mass spectra for the occurrence of nonspecific ligand binding [52, 62-69]. The most direct approach is the reference protein method, which involves the addition of a non-interacting reference protein $\left(\mathrm{P}_{\text {ref }}\right)$ to solution to quantitatively correct for nonspecific ligand binding to the protein/complexes of interest [62]. The method is based on the assumption that nonspecific ligand binding is random, as suggested by the observation that the distribution of 


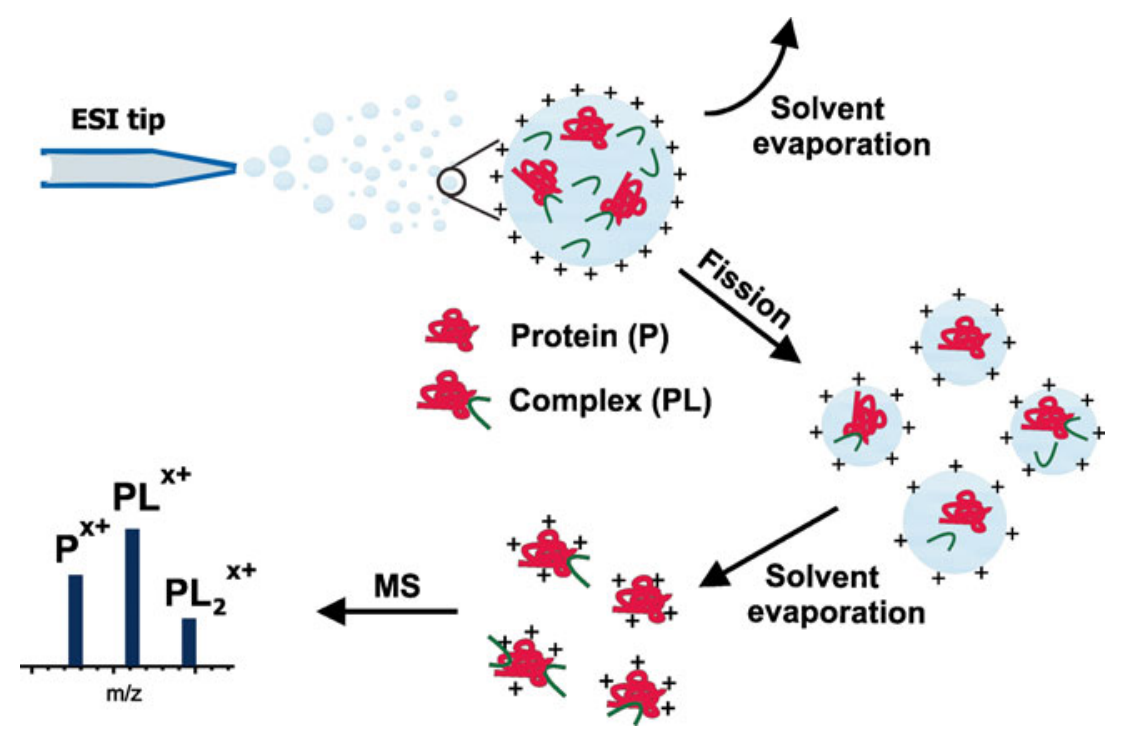

Figure 2. Cartoon of the charge residue model of ESI depicting the formation of nonspecific ligand-protein interactions (false positives). Nonspecific binding of $\mathrm{L}$ to $\mathrm{P}$ and $\mathrm{PL}$ obscures the true binding stoichiometry in solution and introduces error into the $\mathrm{K}_{\mathrm{a}}$ values measured by ESI-MS

nonspecifically bound molecules often resembles that of a Poisson process, and affects equally all protein species present in the ESI droplets. The assumption that in a given experiment ESI-MS experiment, the distribution of nonspecifically bound $\mathrm{L}$ is independent of the nature of the protein has been rigorously tested and shown to be valid for a variety of "ligands," including neutral and charged carbohydrates, amino acids, peptides, and divalent metal ions [62-64, 70]. However, an important caveat is that the distributions on nonspecifically bound ligands should not be perturbed by in-source dissociation. It follows that the "true" abundance of a given $\mathrm{PL}_{q}$ species $\left[A b\left(\mathrm{PL}_{q}\right)\right]$ can be calculated from the apparent (measured) abundance of the $\mathrm{PL}_{q}$ species $\left[A b_{a p p}\left(\mathrm{PL}_{q}\right)\right]$ and the distribution of nonspecific $\mathrm{P}_{r e f} \mathrm{~L}_{q}$ species using the following expression:

$$
\begin{aligned}
A b\left(\mathrm{PL}_{q}\right)= & {\left[A b_{a p p}\left(\mathrm{PL}_{q}\right)-f_{1, \mathrm{P} r e f} A b\left(\mathrm{PL}_{q-1}\right)-\right.} \\
& \left.f_{2, \mathrm{P} r e f} A b\left(\mathrm{PL}_{q_{-2}}\right)-\cdots f_{q, \mathrm{P} r e f} A b(\mathrm{P})\right] / f_{0, \mathrm{P} r e f}
\end{aligned}
$$

where $f_{q, \text { Pref }}$ is the fractional abundance of $\mathrm{P}_{r e f}$ bound to $q$ molecules of L. This correction method has been successfully used in binding studies performed on a variety of protein-ligand interactions, including protein-carbohydrate and protein-metal ion complexes [17, 70]. An example outlining the step-by-step implementation of the correction method is given in Figure 3 for the interaction between the glycosyltransferase B (GTB) and a disaccharide substrate.
An alternative method, called the reporter molecule method, was developed to identify the occurrence of nonspecific protein-protein binding during the ESI process [68]. To implement the method, a non-interacting small molecule $\left(\mathrm{M}_{\mathrm{rep}}\right)$ is added to the solution, at elevated concentration. Differences in the distributions of the small molecule bound nonspecifically to the different protein species present (e.g., monomer versus dimer) is used to establish the occurrence of nonspecific protein-protein binding. The nonspecific probe method was recently developed to identify the occurrence of nonspecific binding between small molecules during the ESI process [69]. In this method, a non-interacting protein $\left(\mathrm{P}_{\mathrm{NS}}\right)$ is added to solution and the distributions of small molecules bound nonspecifically to $\mathrm{P}_{\mathrm{NS}}$ is used to establish whether small molecule complexes originated from solution or they were formed by nonspecific binding. A weakness with both the reporter molecule and nonspecific probe methods is that they do not allow ESI mass spectra to be quantitatively corrected for the occurrence of nonspecific binding. The development of quantitative correction methods suitable for nonspecific protein-protein and small molecule binding would represent important contributions to the field.

\section{ESI-Induced Changes in Solution pH and Temperature}

The $\mathrm{K}_{\mathrm{a}}$ values for protein-ligand interactions in aqueous solution are generally sensitive to $\mathrm{pH}$ and temperature. Both the $\mathrm{pH}$ and the temperature of the solution may be altered by the ESI-MS measurement and lead to changes in $\mathrm{K}_{\mathrm{a}}$, particularly when low solution flow rates are used. Electro- 
(a)

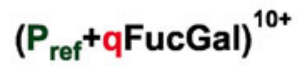

$\left(\mathrm{GTB}_{2}+\mathrm{qFucGal}\right)^{15+}$
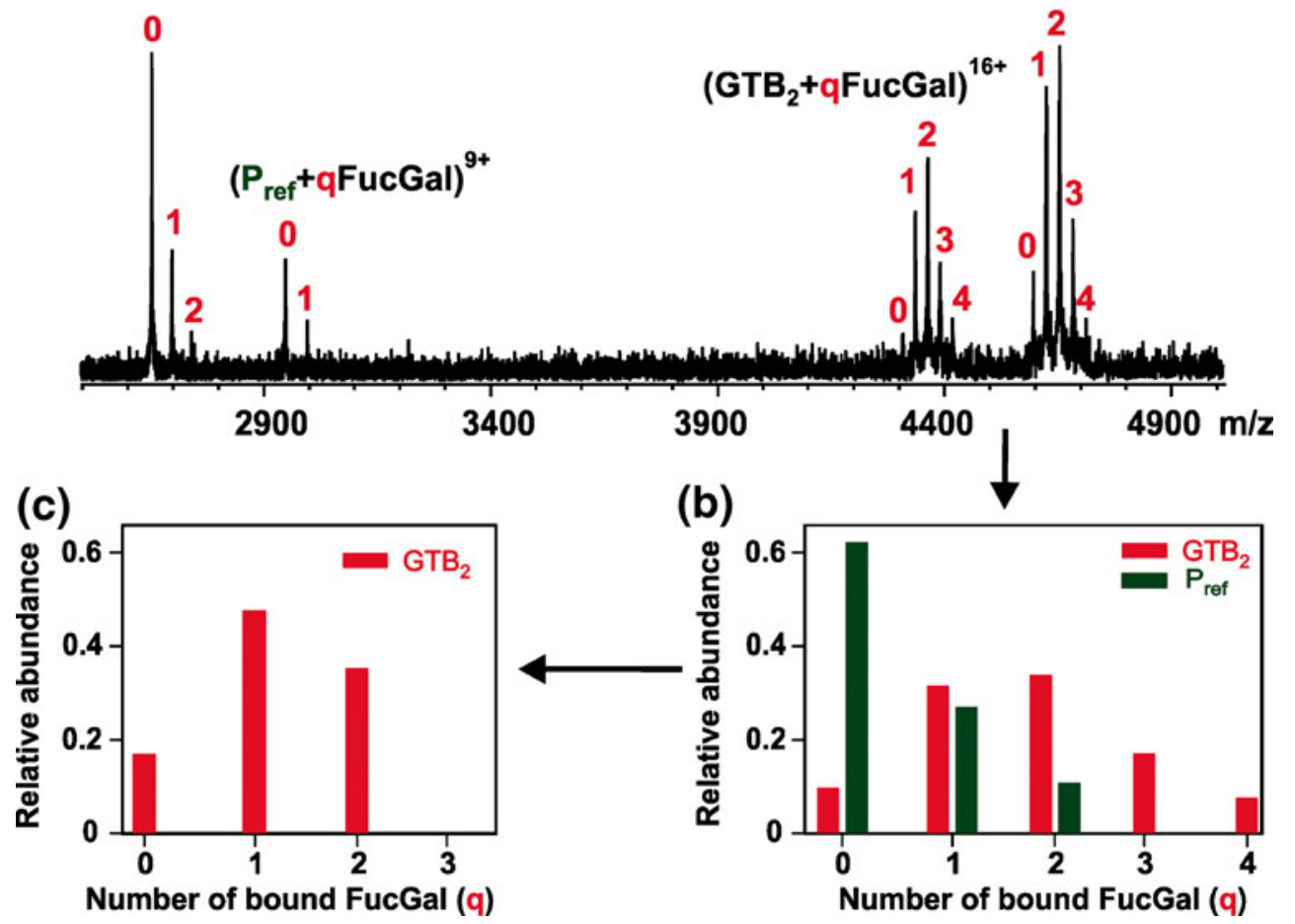

(b)

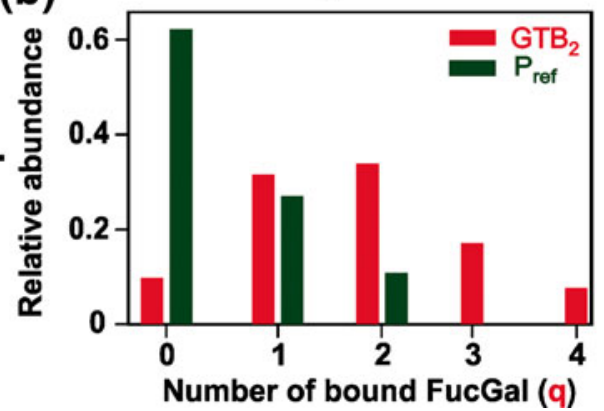

Figure 3. (a) ESI mass spectrum measured for a solution containing the glycosyltransferase GTB homodimer, GTB 2 (7 $\mu \mathrm{M})$, disaccharide acceptor substrate, FucGal $(100 \mu \mathrm{M})$ and reference protein, $P_{\text {ref. }}$ (b) Distribution of FucGal bound to GTB 2 and $P_{\text {ref }}$ determined from mass spectrum. (c) Distribution of FucGal bound to $\mathrm{GTB}_{2}$ after correction for nonspecific binding

chemical reactions, which occur at the electrode in the ESI tip, can alter the composition of the solution [71]. In aqueous solution the dominant electrochemical reactions occurring at a chemically inert electrode are oxidation (positive ion mode) and reduction (negative ion mode) of $\mathrm{H}_{2} \mathrm{O}$ leading to the production of $\mathrm{H}_{3} \mathrm{O}^{+}$and $\mathrm{OH}^{-}$, respectively. At low solution flow rates $(<100 \mathrm{~nL} / \mathrm{min})$, the resulting $\mathrm{pH}$ changes can be large, $>1 \mathrm{pH}$ unit after $30 \mathrm{~min}$ of spraying [14]. The use of ESI solutions with a high buffer capacity or short spraying times $(<10 \mathrm{~min})$ is sufficient to minimize errors in $\mathrm{K}_{a}$ introduced by $\mathrm{pH}$ changes. One must also be on guard against inadvertent changes to the temperature of the solution. Most commercial ESI sources rely on heating of the droplets to accelerate/assist with the desolvation of ions to improve sensitivity. This is commonly achieved by applying heated air or $\mathrm{N}_{2}$ as a drying gas in the region of the ESI tip or sampling of the ESI droplets into a heated metal capillary. Exposure of the ESI tip to heated gas or having the tip in proximity of a heated metal capillary can lead to changes in temperature of a few degrees or more, particularly when using low solution flow rates. It is generally recommended that the actual solution temperature under standard operating conditions be established and the binding data reported at that temperature. It is important to stress that changes in solution temperature, provided they are "controlled," can be exploited for the determination of the temperature-dependence of $K_{a}$. From a van't Hoff analysis, the corresponding $\Delta \mathrm{H}_{\mathrm{a}}$ and $\Delta \mathrm{S}_{\mathrm{a}}$ can be estimated. Several different designs for temperaturecontrolled ESI devices have been reported in recent years [72-75]. One such device uses heated or cooled air to accurately control the temperature of the ESI solution from 0 to $60{ }^{\circ} \mathrm{C}$ [72]. Using this approach, $\Delta \mathrm{H}_{\mathrm{a}}$ and $\Delta \mathrm{S}_{\mathrm{a}}$ values determined for a several protein-carbohydrate interactions were shown to be in good agreement with values determined by ITC $[17,72]$.

\section{Other Challenges}

In addition to the sources of error outlined above, there are also technical issues that currently limit the utility of the direct ESI-MS assay. Among these is the general incompatibility of the assay with "physiological" buffers. In proteinligand binding studies, the primary role of the buffer is to keep the protein stable and minimize protein aggregation. For many proteins, there is often a narrow range of concentration, $\mathrm{pH}$, and ionic strengths, which provides a binding-competent, active protein. Mass spectrometric studies often employ aqueous ammonium acetate solutions (1$200 \mathrm{mM}$ ), with minimal nonvolatile salts or detergents added 
to the solution. In contrast, buffers (e.g., PBS, citrate, HEPES, TRIS) employed with "gold standard" techniques, such as ITC, are widely varied and typically optimized with salts and co-factors to stabilize the protein of interest and ensure relevance to physiological conditions. In fact, there are many reported examples where buffer optimization was a critical step in enabling the characterization of the interaction. A variety of strategies have been proposed for ESI-MS analysis of solutions containing physiological buffers at relevant concentrations, including the use of high ammonium acetate concentrations [76, 77], carrying out ESI in the presence of high velocity air (gas) [78], and decoupling the sample solution from the ESI process through the use of desorption electrospray ionization (DESI) [79]. However, for the direct ESI-MS binding assay to become a truly universal binding assay, significant technological/methodological advances in this area are still needed.

Another challenge limiting the widespread implementation of the direct ESI-MS binding assay is automation of the technique. Binding experiments are often performed by direct infusion from a nanoESI tip composed of a gold coated tapered glass capillary with an orifice of $\sim 5 \mu \mathrm{m}$ in diameter. NanoESI is exquisitely sensitive due to efficient desolvation [80] and is particularly useful when protein quantities are limited. However, the sample solution must be manually loaded into each nanoESI tip, thereby limiting the throughput of the binding assay. An alternative approach is "chip" based nanoESI sources, such as the Advion Triversa, which is compatible with a variety of commercial mass spectrometers. With the Triversa sample injection from a 96 or 384 well plate can be automated, with each sample electrosprayed from a single-use nozzle etched in a silicon wafer. Chip-based nanoESI sources have shown promise for the analysis of protein-protein, protein-oligonucleotide [81], and protein-small molecule interactions [82]. However, in our experience, pulled tip nanoESI sources generally give the best sensitivity when analyzing large complexes $(>200 \mathrm{kDa})$.

\section{Future Directions}

Although there remain a number of outstanding challenges to the routine implementation of the ESI-MS assay and, consequently, the widespread adoption of the technique, the methodological advances described above have significantly improved the reliability of the direct ESI-MS assay and its "application space" is expected to grow in the coming years. Two areas where the ESI-MS technique will likely play prominent roles are the analysis of hydrophobic protein-ligand interactions and screening to identify drug candidates. To date, there have been few reports of the application of ESI-MS to directly characterize hydrophobic protein-ligand interactions $[23,83-86]$. In fact, it has been suggested that the direct ESIMS assay does not give results that accurately reflect the solution equilibria for protein-ligand interactions that are dominated by hydrophobic bonding [87]. The underlying

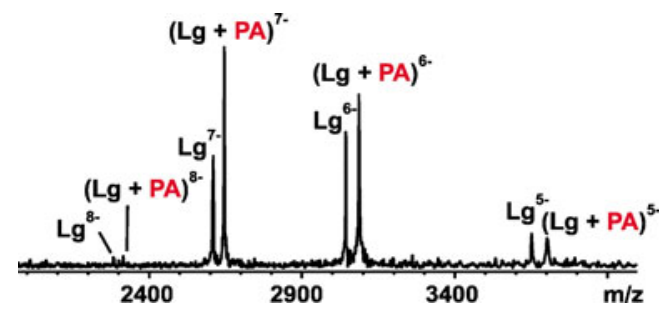

Figure 4. ESI mass spectrum measured for an aqueous ammonium acetate solution containing $12 \mu \mathrm{M} \beta$-lactoglobulin $(\mathrm{Lg})$ and $11 \mu \mathrm{M}$ palmitic acid (PA). The $\mathrm{K}_{\mathrm{a}}$ value determined by ESI-MS $\left(3.7 \pm 0.2 \times 10^{5} \mathrm{M}^{-1}\right)$ agrees with the value determined using a competitive fluorescence assay $(5.1 \pm 0.2 \times$ $\left.10^{5} \mathrm{M}^{-1}\right)$ [23]

argument is that because hydrophobic bonding requires the presence of water, the dehydrated complexes are unstable in the gas phase $[49,88]$. However, recently acquired kinetic data indicate the opposite - the kinetic stability is greater in the gas phase than in solution [89]. Therefore, using gentle sampling conditions and stabilizing additives it should be possible to measure meaningful $\mathrm{K}_{\mathrm{a}}$ values for a wide variety of biologically-important hydrophobic protein-ligand interactions by ESI-MS (Figure 4) [23].

Certainly, the ESI-MS technique will find greater application in the identification of therapeutic leads. In principle, the complex between a protein target and a modestly potent small molecule ligand can be detected directly and identified in single experiment. One advantage of the ESI-MS methodology is that it is relatively straightforward to perform a multiplexed experiment in which mixtures of hundreds of small molecule compounds are simultaneously incubated with the target protein [21, 28-32]. The highest affinity ligands can be directly identified from the ESI mass spectra provided the library is appropriately "mass encoded," such that each compound in the mixture pool has a unique MW (Figure 5). In cases where the library contains multiple compounds with the same MW, a

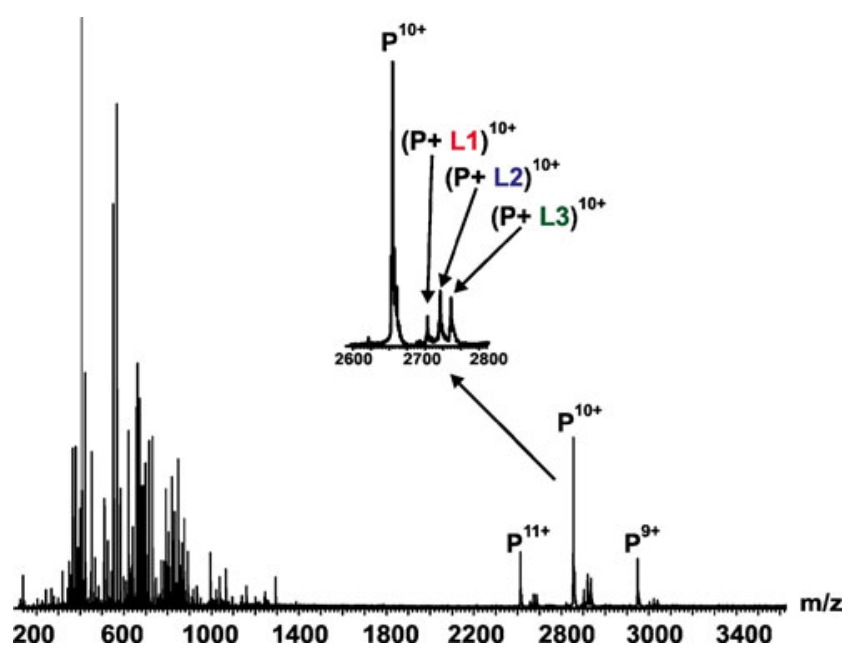

Figure 5. ESI mass spectrum acquired in positive ion mode for a solution of ScFv $(P, 10 \mu \mathrm{M})$ and 204 carbohydrates (2 $\mu \mathrm{M}$ each), including three specific ligands, L1, L2, and L3 
"catch and release" strategy, in which bound ligands are released (as ions) from the complex using collisional or radiative heating followed by ion mobility separation or ion activation/dissociation and product ion measurement, can be employed [21, 28-32, 90]. A highly attractive feature of this approach is that it lends itself to the analysis of unpurified natural product extracts, a capability that is not found with other screening assays. Furthermore, this "catch and release" methodology may have utility in screening intact heterogeneous proteins where ESI-MS analysis often results in complex, unresolved mass spectra. As MS instrumentation and methods continue to evolve it may soon be possible to screen libraries against more "difficult targets" such as integral membrane proteins.

\section{Conclusions}

So, has the direct ESI-MS assay matured to the point where protein-ligand binding measurements can be viewed as routine? The answer is no. The current reality is that if conflicting $\mathrm{K}_{\mathrm{a}}$ values were measured by multiple assays, the ESI-MS data would, in many cases, be treated as the least reliable. That being said, there have been significant methodological advances, which minimize many of the common sources of error in ESI-MS binding measurements. For example, much progress has been made on the issues of false positives (nonspecific ligand binding) and non-uniform response factors, although a lack of awareness of these problems persists. Arguably, the greatest roadblock to the widespread adoption of direct ESI-MS assay is the possibility of false negatives resulting from the inability to reliably probe protein-ligand interactions that are kinetically labile at or near room temperature. While only time will tell if the direct ESI-MS assay will become a truly routine tool for the detection and quantification of protein-ligand interactions, the technique already represents an important addition to the arsenal of available binding assays.

\section{Acknowledgments}

The authors acknowledge the Natural Sciences and Engineering Research Council of Canada and the Alberta Glycomics Centre for generous funding.

\section{References}

1. Cooper, M.A.: Optical biosensors in drug discovery. Nature Rev. Drug Discov. 1, 515-528 (2002)

2. De Azevedo Jr., W., Dias, R.: Experimental approaches to evaluate the thermodynamics of protein-drug interactions. Current Drug Targets $\mathbf{9}$, 1071-1076 (2008)

3. Slon-Usakiewicz, J.J., Ng, W., Dai, J.-R., Pasternak, A., Redden, P.R.: Frontal affinity chromatography with MS detection (FAC-MS) in drug discovery. Drug Discov. Today 10, 409-416 (2005)

4. Larsen, K., Thygesen, M.B., Guillaumie, F., Willats, W.G.T., Jensen, K.J.: Solid-phase chemical tools for glycobiology. Carbohydr. Res. 341, 1209-1234 (2006)

5. Matulis, D., Kranz, J.K., Salemme, F.R., Todd, M.J.: Thermodynamic stability of carbonic anhydrase: Measurements of binding affinity and stoichiometry using ThermoFluor. Biochemistry 44, 5258-5266 (2005)
6. Peters, P., Meyer, B.: NMR spectroscopy techniques for screening and identifying Ligand binding to protein receptors. Angew. Chem. Int. Ed. 42, 864-890 (2003)

7. Loo, J.A.: Studying noncovalent protein complexes by electrospray ionization mass spectrometry. Mass Spectrom. Rev. 16, 1-23 (1997)

8. Daniel, J.M., Friess, S.D., Rajagopalan, S., Wendt, S., Zenobi, R.: Quantitative determination of noncovalent binding interactions using soft ionization mass spectrometry. Int. J. Mass Spectrom. 216, 1-27 (2002)

9. Schug, K.A.: Solution phase enantioselective recognition and discrimination by electrospray ionization-mass spectrometry: State-of-the-art, methods, and an eye towards increased throughput measurements. Comb. Chem. High Throughput Screen. 10, 301-316 (2007)

10. Heck, A.J.R., Van Den Heuvel, R.H.H.: Investigation of intact protein complexes by mass spectrometry. Mass Spectrom. Rev. 23, 368-389 (2004)

11. Katta, V., Chait, B.T.: Observation of the heme-globin complex in native myoglobin by electrospray-ionization mass spectrometry. J. Am. Chem. Soc. 113, 8534-8535 (1991)

12. Ganem, B., Li, Y.-T., Henion, J.D.: Observation of noncovalent enzyme-substrate and substrate-product complexes by ion spray MS. J. Am. Chem. Soc. 113, 7818-7819 (1991)

13. Ogorzalek Loo, R.R., Goodlett, D.R., Smith, R.D., Loo, J.A.: Observation of a noncovalent ribonuclease S-protein/ S-peptide complex by electrospray ionization mass spectrometry. J. Am. Chem. Soc. 115, 4391-4392 (1993)

14. Wang, W., Kitova, E.N., Klassen, J.S.: Influence of solution and gas phase processes on protein-carbohydrate binding affinities determined by nanoelectrospray fourier transform ion cyclotron resonance mass spectrometry. Anal. Chem. 75, 4945-4955 (2003)

15. Shoemaker, G.K., Soya, N., Palcic, M.M., Klassen, J.S.: Temperaturedependent cooperativity in donor-acceptor substrate binding to the human blood group glycosyltransferases. Glycobiology 18, 587-592 (2008)

16. Soya, N., Shoemaker, G.K., Palcic, M.M., Klassen, J.S.: Comparative study of substrate and product binding to the human $\mathrm{ABO}(\mathrm{H})$ blood group Glycosyltransferases. Glycobiology 19, 1224-1234 (2009)

17. Rademacher, C., Shoemaker, G.K., Kim, H.-S., Zheng, R.B., Taha, H., Liu, C., Nacario, R.C., Schriemer, D.C., Klassen, J.S., Peters, T., Lowary, T.L.: Ligand specificity of CS-35, a monoclonal antibody that recognizes mycobacterial lipoarabinomannan: A model system for Oligofuranoside - protein recognition. J. Am. Chem. Soc. 129, 1048910502 (2007)

18. Jorgensen, T.J.D., Roepstorff, P., Heck, A.J.R.: Direct determination of solution binding constants for noncovalent complexes between bacterial cell wall peptide analogues and vancomycin group antibiotics by electrospray ionization mass spectrometry. Anal. Chem. 70, 44274432 (1998)

19. Jecklin, M.C., Touboul, D., Bovet, C., Wortmann, A., Zenobi, R.: Which electrospray-based ionization method best reflects protein-ligand interactions found in solution? A comparison of ESI, NanoESI, and ESSI for the determination of dissociation constants with mass spectrometry. J. Am. Soc. Mass Spectrom. 19, 332-343 (2008)

20. Yu, Y.H., Kirkup, C.E., Pi, N., Leary, J.A.: Characterization of noncovalent protein-ligand complexes and associated enzyme intermediates of GlcNAc-6-O-Sulfotransferase by electrospray ionization FT-ICR mass spectrometry. J. Am. Soc. Mass Spectrom. 15, 1400-1407 (2004)

21. Hofstadler, S.A., Sannes-Lowery, K.A.: Applications of ESI-MS in drug discovery: Interrogation of noncovalent complexes. Nat. Rev. Drug Discov. 5, 585-595 (2006)

22. Ganem, B., Henion, J.D.: Going gently into flight: Analyzing noncovalent interactions by mass spectrometry. Bioorg. Med. Chem. 11, 311-314 (2003)

23. Liu, L., Kitova, E.N., Klassen, J.S.: Quantifying protein-fatty acid interactions using electrospray ionization mass spectrometry. J. Am. Soc. Mass Spectrom. 22, 310-318 (2011)

24. Donoho, D.L., Johnstone, J.M., Sternt, A.S., Hoch, J.C.: Does the maximum-entropy method improve sensitivity. Proc. Natl. Acad. Sci. USA 87, 5066-5068 (1990)

25. Kempen, E.C., Brodbelt, J.S.: A method for the determination of binding constants by electrospray ionization mass spectrometry. Anal. Chem. 72, 5411-5416 (2000)

26. McCammon, M.G., Scott, D.J., Keetch, C.A., Greene, L.H., Purkey, H. E., Petrassi, H.M., Kelly, J.W., Robinson, C.V.: Screening transthyretin 
amyloid fibril inhibitors: Characterization of novel multiprotein, multiligand complexes by mass spectrometry. Structure 10, 851-863 (2002)

27. Yu, Y., Sweeney, M.D., Saad, O.M., Crown, S.E., Handel, T.M., Leary, J.A.: Chemokine-Glycosaminoglycan binding - specificity for CCR2 ligand binding to highly sulfated oligosaccharides using FTICR mass spectrometry. J. Biol. Chem. 280, 32200-32208 (2005)

28. Cummins, L.L., Chen, S., Blyn, L.B., Sannes-Lowery, K.A., Drader, J. J., Griffey, R.H., Hofstadler, S.A.: Multitarget affinity/specificity screening of natural products: Finding and characterizing high-affinity ligands from complex mixtures by using high-performance mass spectrometry. J. Nat. Prod. 66, 1186-1190 (2003)

29. Wigger, M., Eyler, J.R., Benner, S.A., Li, W., Marshall, A.G.: Fourier transform-ion cyclotron resonance mass spectrometric resolution, identification, and screening of non-covalent complexes of Hck Src homology 2 domain receptor and ligands from a 324-member peptide combinatorial library. J. Am. Soc. Mass Spectrom. 13, 1162-1169 (2002)

30. Abzalimov, R.R., Dubin, P.L., Kaltsahov, I.A.: Glycosaminoglycans as naturally occuring combinatorial libraries: Spectrometry-based strategy for characterization of anti-thrombin interaction strategy with low molecular weight heparin and heparin oligomers. Anal. Chem. 79, 6055-6063 (2007)

31. Cheng, X., Chen, R., Bruce, J.E., Schwartz, B., Anderson, G.A., Hofstadler, S.A., Gale, D.C., Smith, R.D.: Using electrospray-ionization fticr mass-spectrometry to study competitive-binding of inhibitors to carbonic-anhydrase. J. Am. Chem. Soc. 117, 8859-8860 (1995)

32. Gao, J., Cheng, X., Chen, R., Sigal, G.B., Bruce, J.E., Schwartz, B.L., Hofstadler, S.A., Anderson, G.A., Smith, R.D., Whitesides, G.M.: Screening derivatized peptide libraries for tight binding inhibitors to carbonic anhydrase II by electrospray ionization mass spectrometry. $J$. Med. Chem. 39, 1949-1955 (1996)

33. Cederkvist, F.H., Zamfir, A.D., Bahrke, S., Eijsink, V.G.H., Sørlie, M., Peter-Katalinic, J., Peter, M.G.: Identification of a high-affinity-binding oligosaccharide by $(+)$ nanoelectrospray quadrupole time-of-flight tandem mass spectrometry of a noncovalent enzyme-ligand complex. Angew. Chem. Int. Ed. 45, 2429-2434 (2006)

34. Krishnaswamy, S.R., Williams, E.R., Kirsch, J.F.: Free energies of protein-protein association determined by electrospray ionization mass spectrometry correlate accurately with values obtained by solution methods. Protein Sci. 15, 1465-1475 (2006)

35. Wortmann, A., Jecklin, M.C., Touboul, D., Badertscher, M., Zenobi, R. Binding constant determination of high-affinity protein-ligand complexes by electrospray ionization mass spectrometry and ligand competition. J. Mass Spectrom. 43, 600-608 (2008)

36. El-Hawiet, A., Kitova, E.N., Liu, L., Klassen, J.S.: Quantifying labile protein-ligand interactions using electrospray ionization mass spectrometry. J. Am. Soc. Mass Spectrom. 21, 1893-1899 (2010)

37. Kitova, E.N., Kitov, P.I., Paszkiewicz, E., Kim, J., Mulvey, G.L., Armstrong, G.D., Bundle, D.R., Klassen, J.S.: Affinities of Shiga toxins 1 and 2 for univalent and oligovalent Pk-trisaccharide analogs measured by electrospray ionization mass spectrometry. Glycobiology 17, 1127-1137 (2007)

38. Peschke, M., Verkerk, U.H., Kebarle, P.: Features of the ESI mechanism that affect the observation of multiply charged noncovalent protein complexes and the determination of the association constant by the titration method. J. Am. Soc. Mass Spectrom. 15, 1424-1434 (2004)

39. Gross, J., Xavier, A., Gross, M.: RNA Neomycin Complexes Analyzed by Electrospray and UV-MALDI-MS. Abstracts of Papers, 49th ASMS Conference on Mass Spectrometry and Allied Topics; Chicago, IL; June 2001.

40. Chitta, R.K., Rempel, D.L., Gross, M.L.: Determination of affinity constants and response factors of the noncovalent dimer of gramicidin by electrospray ionization mass spectrometry and mathematical modeling. J. Am. Soc. Mass Spectrom. 16, 1031-1038 (2005)

41. Wilcox, J.M., Rempel, D.L., Gross, M.L.: Method of measuring oligonucleotide-metal affinities: Interactions of the thrombin binding aptamer with $\mathrm{K}^{+}$and $\mathrm{Sr}^{2+}$. Anal. Chem. 80, 2365-2371 (2008)

42. Gabelica, V., Galic, N., Rosu, F., Houssier, C., De Pauw, E.: Influence of response factors on determining equilibrium association constants of noncvalent complexes by electrospray ionization mass spectrometry. $J$. Mass Spectrom. 38, 491-501 (2003)

43. Gabelica, V., Rosu, F., De Pauw, E.: A simple method to determine electrospray response factors of noncovalent complexes. Anal. Chem. 81, 6708-6715 (2009)

44. Mathur, S., Badertscher, S., Scott, M., Zenobi, R.: Critical evaluation of mass spectrometric measurement of dissociation constants: Accuracy and cross-validation against surface plasmon resonance and circular dichroism for the calmodulin-melittin system. Phys. Chem. Chem. Phys. 9, 6187-6198 (2007)

45. Wortmann, A., Rossi, F., Lelais, G., Zenobi, R.: Determination of zinc to $\beta$-peptide binding constants with electrospray ionization mass spectrometry. J. Mass Spectrom. 40, 777-784 (2005)

46. Van Dongen, W.D., Heck, A.J.R.: Binding of selected carbohydrates to Apo-Concanavalin a studied by electrospray ionization mass spectrometry. Analyst 125, 583-589 (2000)

47. Sun, J., Kitova, E.N., Klassen, J.S.: Method for stabilizing proteinligand complexes in nanoelectrospray ionization mass spectrometry. Anal. Chem. 79, 416-425 (2007)

48. Clark, S.M., Konermann, L.: Determination of ligand-protein dissociation constants by electrospray mass spectrometry-based diffusion measurements. Anal. Chem. 76, 7077-7083 (2004)

49. Robinson, C.V., Chung, E.W., Kragelund, B.B., Knudsen, J., Aplin, R. T., Poulsen, F.M., Dobson, C.M.: Probing the nature of noncovalent interactions by mass spectrometry. A study of protein-CoA ligand binding and assembly. J. Am. Chem. Soc. 118, 8646-8653 (1996)

50. Bagal, D., Kitova, E.N., Liu, L., El-Hawiet, A., Schnier, P.D., Klassen, J.S.: Gas phase stabilization of noncovalent protein complexes formed by electrospray ionization. Anal. Chem. 81, 7801-7806 (2009)

51. Xie, Y., Zhang, J., Yin, S., Loo, J.A.: Top-down ESI-ECD-FT-ICR mass spectrometry localizes noncovalent protein-ligand binding sites. $J$. Am. Chem. Soc. 128, 14432-14433 (2006)

52. Hossain, B.M., Konermann, L.: Pulsed hydrogen/deuterium exchange MS/MS for studying the relationship between noncovalent protein complexes in solution and in the gas phase after electrospray ionization. Anal. Chem. 78, 1613-1619 (2006)

53. Hunter, E.P., Lias, S.G.: Evaluated gas phase basicities and proton affinities of molecules: An update. Phys. Chem. Ref. Data 27, 413-656 (1998)

54. Taft, R.W., Anvia, F., Taagepera, M., Catalan, J., Elguero, J.: Electrostatic proximity effects in the relative basicities and acidities of pyrazole, imidazole, pyridazine, and pyrimidine. J. Am. Chem. Soc. 108, 3237-3239 (1986)

55. Sakamoto, S., Fujita, M., Kim, K., Yamaguchi, K.: Characterization of self-assembling nano-sized structures by means of coldspray ionization mass spectrometry. Tetrahedron 56, 955-964 (2000)

56. Nishimura, S.-I., Nagahori, N., Takaya, K., Tachibana, Y., Miura, N., Monde, K.: Direct observation of sugar-protein, sugar-sugar, and sugar-water complexes by cold-spray ionization time-of-flight mass spectrometry. Angew. Chem. Int. Ed. 44, 571-575 (2005)

57. Miras, H.N., Wilson, E.F., Cronin, L.: Unravelling the complexities of inorganic and supramolecular self-assembly in solution with electrospray and cryospray mass spectrometry. Chem. Commun. 11, 12971311 (2009)

58. Dole, M., Mack, L.L., Hines, R.L., Mobley, R.C., Ferguson, L.D., Alice, M.B.: Molecular beams of macroions. J. Chem. Phys. 49, 22402249 (1968)

59. Wang, W., Kitova, E.N., Klassen, J.S.: Nonspecific protein-carbohydrate complexes produced by nanoelectrospray ionization. factors influencing their formation and stability. Anal. Chem. 77, 3060-3071 (2005)

60. Dybvik, A.I., Norberg, A.L., Schute, V., Soltwisch, J., Peter-Katalinic, J., Varum, K.M., Eijsink, V.G.H., Dreisewerd, K., Mormann, M., Sørlie, M.: Analysis of noncovalent chitinase-chito-oligosaccharide complexes by infrared-matrix assisted laser desorption ionization and nanoelectrospray ionization mass spectrometry. Anal. Chem. 83, 40304036 (2011)

61. Wang, W., Kitova, E.N., Klassen, J.S.: Bioactive recognition sites may not be energetically preferred in protein-carbohydrate complexes in the gas phase. J. Am. Chem. Soc. 125, 13630-13631 (2003)

62. Sun, J., Kitova, E.N., Wang, W., Klassen, J.S.: Method for distinguishing specific from nonspecific protein-ligand complexes in nanoelectrospray ionization mass spectrometry. Anal. Chem. 78, 3010-3018 (2006)

63. Sun, N., Soya, N., Kitova, E.N., Klassen, J.S.: Nonspecific interactions between proteins and charged biomolecules in electrospray ionization mass spectrometry. J. Am. Soc. Mass Spectrom. 21, 472-481 (2010)

64. Sun, J., Kitova, E.N., Sun, N., Klassen, J.S.: Method for identifying nonspecific protein-protein interactions in nanoelectrospray ionization mass spectrometry. Anal. Chem. 79, 8301-8311 (2007)

65. Daubenfeld, T., Bouin, A.P., van der Rest, G.: A deconvolution method for the separation of specific versus nonspecific interactions in 
noncovalent protein-ligand complexes analyzed by ESI-FT-ICR mass spectrometry. J. Am. Soc. Mass Spectrom. 17, 1239-1248 (2006)

66. Shimon, L., Sharon, M., Horovitz, A.: A method for removing effects of nonspecific binding on the distribution of binding stoichiometries: Application to mass spectroscopy data. Biophys. J. 99, 1645-1649 (2010)

67. Lane, L.A., Ruotolo, B.T., Robinson, C.V., Favrin, G., Benesch, J.L.P.: A Monte Carlo approach for assessing the specificity of protein oligomers observed in nano-electrospray mass spectra. Int. J. Mass Spectrom. 283, 169-177 (2009)

68. Sun, N., Sun, J., Kitova, E.N., Klassen, J.S.: Identifying nonspecific ligand binding in electrospray ionization mass spectrometry using the reporter molecule method. J. Am. Soc. Mass Spectrom. 20, 1242-1250 (2009)

69. Kitova, E.N., Soya, N., Klassen, J.S.: Identifying specific smallmolecule interactions using electrospray ionization mass spectrometry. Anal. Chem. 83, 5160-5167 (2011)

70. Deng, L., Sun, N., Kitova, E.N., Klassen, J.S.: Direct quantification of protein-metal ion affinities by electrospray ionization mass spectrometry. Anal. Chem. 82, 2170-2174 (2010)

71. Van Berkel, G.J., Asano, K.G., Schnier, P.D.: Electrochemical processes in a wire-in-a-capillary bulk-loaded, nano-electrospray emitter. J. Am. Soc. Mass Spectrom. 12, 853-862 (2001)

72. Daneshfar, R., Kitova, E.N., Klassen, J.S.: Determination of proteinligand association thermochemistry using variable-temperature nanoelectrospray mass spectrometry. J. Am. Chem. Soc. 126, 4786-4787 (2004)

73. Frahm, J.L., Muddiman, D.C., Burke, M.J.: Leveling response factors in the electrospray ionization process using a heated capillary interface. $J$. Am. Soc. Mass Spectrom. 16, 772-778 (2005)

74. Benesch, J.L.P., Sobott, F., Robinson, C.V.: Thermal dissociation of multimeric protein complexes by using nanoelectrospray mass spectrometry. Anal. Chem. 75, 2208-2214 (2003)

75. Wang, G., Abzalimov, R.R., Kaltashov, I.A.: Direct monitoring of heatstressed biopolymers with temperature-controlled electrospray ionization mass spectrometry. Anal. Chem. 83, 2870-2876 (2011)

76. Hernandez, H., Robinson, C.V.: Determining the stoichiometry and interactions of macromolecular assemblies from mass spectrometry. Nature Prot. 2, 715-726 (2007)

77. Iavarone, A.T., Udekwu, O.A., Williams, E.R.: Buffer loading for counteracting metal salt-induced signal suppression in electrospray ionization. Anal. Chem. 76, 3944-3950 (2004)

78. Yang, P., Cooks, R.G., Ouyang, Z., Hawkridge, A.M., Muddiman, D. C.: Gentle protein ionization assisted by high-velocity gas flow. Anal. Chem. 77, 6174-6183 (2005)
79. Ferguson, C.N., Benchaar, S.A., Miao, Z., Loo, J.A., Chen, H.: Direct ionization of large proteins and protein complexes by desorption electrospray ionization-mass spectrometry. Anal. Chem. 83, 64686473 (2011)

80. Valaskovic, G.A., Kelleher, N.L., Little, D.P., Aaserud, D.J., McLafferty, F.W.: Attomole-sensitivity electrospray source for large-molecule mass spectrometry. Anal. Chem. 67, 3802-3805 (1995)

81. Ritschel, T., Atmanene, C., Reuter, K., Van Dorsselaer, A., SanglierCianferani, S., Klebe, G.: An integrative approach combining noncovalent mass spectrometry, enzyme kinetics and X-ray crystallography to decipher Tgt protein-protein and protein-RNA interaction. J. Mol. Biol. 393, 833-847 (2009)

82. Bovet, C., Ruff, M., Wortmann, A., Eiler, S., Granger, F., Gerrits, B., Moras, D., Zenobi, R.: Identification of endocrine-disrupting compounds using nanoelectrospray ionization mass spectrometry. Chimia 62, 329-334 (2008)

83. Demmers, J.A.A., Haverkamp, J., Heck, A.J.R., Koeppe II, R.E., Killian, J. A.: Electrospray ionization mass spectrometry as a tool to analyze hydrogen/deuterium exchange kinetics of transmembrane peptides in lipid bilayers. Proc. Natl. Acad. Sci. U. S. A. 97, 3189-3194 (2000)

84. Barrera, N.P., Di Bartolo, N., Booth, P.J., Robinson, C.V.: Micelles protect membrane complexes from solution to vacuum. Science 321, 243-246 (2008)

85. Barrera, N.P., Isaacson, S.C., Zhou, M., Bavro, V.N., Welch, A., Schaedler, T.A., Seeger, M.A., Miguel, R.N., Korkhov, V.M., van Veen, H.W., Venter, H., Walmsley, A.R., Tate, C.G., Robinson, C.V.: Mass spectrometry of membrane transporters reveals subunit stoichiometry and interactions. Nature Methods 6, 585-587 (2009)

86. Zhou, M., Morgner, N., Barrera, N.P., Politis, A., Isaacson, S.C., Matak-Vinković, D., Murata, T., Bernal, R.A., Stock, D., Robinson, C. V.: Mass spectrometry of intact V-Type ATPases reveals bound lipids and the effects of nucleotide binding. Science 334, 380-385 (2011)

87. Bich, C., Baer, S., Jecklin, M.C., Zenobi, R.: Probing the hydrophobic effect of noncovalent complexes by mass spectrometry. J. Am. Soc. Mass Spectrom. 21, 286-289 (2010)

88. Yin, S., Xie, Y., Loo, J.A.: Mass spectrometry of protein-ligand complexes: Enhanced gas-phase stability of ribonuclease-nucleotide complexes. J. Am. Soc. Mass Spectrom. 19, 1199-1208 (2008)

89. Liu, L., Michelsen, K., Kitova, E.N., Schnier, P.D., Klassen, J.S.: Evidence that water can reduce the kinetic stability of protein-hydrophobic ligand interactions. J. Am. Chem. Soc. 132, 17658-17660 (2010)

90. El-Hawiet, A., Shoemaker, G.K., Daneshfar, R., Kitova, E.N., Klassen, J.S.: Applications of a Catch and Release Electrospray Ionization Mass Spectrometry Assay for Carbohydrate Library Screening. Anal. Chem. in press. 